\title{
Workshop GURAME "Guru Asyik Menyenangkan/Fun Teachers" at Darul Hasan Padang Sidhuan School
}

\author{
Author \\ Ayunda Sabrina Sormin, Laila Tussifah, Khairunnisah \\ Correspondence \\ English Department Universitas of Muhammadiyah Tapanuli Selatan
}

\begin{abstract}
Teachers are the spearhead of educational success. Learning will be enhanced if the teacher is able to provide fun learning and meaningful activities. However, to be a fun teacher is not an easy task to create and implement. There are so many issues that often emerge, one of them is the inability of teachers to detect learning modality as the first step in determining the appropriate learning strategies in the classroom. This misunderstanding ultimately leads to uniform learning that causes problems in learning. In addition, the lack of understanding and use of ice breaking as one way to break the ice in the class and selection of ice breaking activities in accordance with teaching materials is worth contributing. Thus, these two things are still very necessary to understand in managing the class because these two things lead to pedagogic competence that must be owned by teachers according to Law no 4 of 2005. Able to understand learners, designing learning and evaluating learning outcomes. The purpose of this Workshop activity is (1) the teacher is able to detect learning modality to jump-start learners' learning potential (2) Teachers are able to master ice breaking as a trick to create a fun class. Because mastering these two things will help teachers in creating and managing the class become fun. This devotion was held at Darul Hasan Foundation in Padang Sidempuan City, followed by 50 teachers. The result of the GURAME workshop is that the participants have been able to detect learning modality, understand the application of ice breaking in the classroom as well as motivated to keep learning to be fun.
\end{abstract}

Keywords: GURAME, master fun, crave learning

Received: 15 December 2017. Accepted: 15 January 2018

\section{Introduction}

Padangsidempuan city is one of education city in North Sumatera Province. It has approximately 15 universities / institutes / colleges / private and public education colleges, 13 units of kindergarten, 91 units of SD / MIN, 34 units of SMP / MTs and 37 units of SMA / MA / SMK both public and private (source: BPS Padangsidempuan city). With many educational institutions, education problems are also increasingly complex. The quality of educators, the availability of infrastructure, internal and external factors of learners and the environment are various factors that must be addressed continuously in an effort to improve the quality of education.

One of the main factors in the success of education is the quality of teachers. Master is the most fundamental spearhead in realizing education. To educate the students, according to Law No. 14 of 2005 on Teachers and Lecturers, that every teacher must have 4 competencies, one of which is pedagogic competence. This pedagogic competence requires teachers to be able to manage the learning process of learners. It is in this management process that often creates problems.

Based on observations of researchers from several high school and junior high schools located in Padang Sidempuan, some teachers still maintain a rigid learning pattern. With an old-fashioned method that makes the class boring. The ability of teachers in managing the class is still not maximized. There are still many teachers who use the lecture method completely without modifying it with student performance. Mastery of ice breaking as one technique to solve the stiffness and eliminate the boredom of students has also not been applied maximally. An understanding of the concentration level of students in minutes is not included in the classroom teaching method. Yet it is clear, the change of paradigm of teaching into learning is the starting point of reference that the process of learning in class should happen two ways, the feedback is one sign of success of learning. This is still a major learning problem. (Sormin, 2016)

The Student Center should become a preferred activity in every learning process because learning by doing will be more appropriate and memorized 
in learners' long-term memory. In addition, many teachers also often make all learners have similar way to learn. Although there are some human learning modalities that become the appropriate way of learning and will bring the learning process into a fun atmosphere. Because every student must have a "dominant" learning style and not all students have the same understanding of learning modalities which is very important to be mastered by the teacher. The teacher should not only understand, but also master how to boost the potential of learners by understanding how to learn.

These learning problems must be managed by teachers in the learning process. And, the first effective solution for the above problems is to be a fun teacher. Because, effective learning will only be generated from teachers who can mix with the learners. Once teachers are able to mingle with learners and have attachments with them, the classroom as a learning process space will be a very enjoyable place for learners. Fun teacher (GURAME) will be the main solution to make learners addicted to learning.

Based on preliminary discussions with partner schools, it is concluded that the problem of similar way of learning is still a polemic for them. The lack of knowledge about learning modality as a powerful way to detect the way of learning in accordance with learners make learning tend to be unidirectional and the material which is delivered does not stay long in learners' long-term memory. The term they often say is, "Entering left ear going out right ear".

In addition, other problems in managing the class is not all of teachers can understand the importance of ice breaking in the learning process to avoid the rigidness of the class and monotonous conditions. Learners need a pause in learning, but do not "run away" from the topic being discussed. Using ice breaking in the learning process will help students stay attentive in learning. Giving space on their mind to refresh can keep the material delivered in long term memory. For that, every teacher must be a fun person, so the teacher will make the class fun and learners will be addicted to learning. Based on this, the workshop aims to: (1) Give teachers an understanding about learning modality and helping teachers to detect students' learning modality (2) Increasing teachers' knowledge about importance of ice breaking in learning and guiding teachers to be more creative in presenting ice breaking in class
(3) Creating learning activity as a place for sharing and upgrading knowledge.

\section{Method of Implementation}

Based on the problems that have been pointed out, then in the activities of community engagement (IbM) the method of implementation used is education in the form of training and workshop.

This workshop is held so that the teachers no longer do the similar way of teaching in class and able to choose the right ice breaking according to the material.

The learning curriculum that is followed by teachers is as follows:

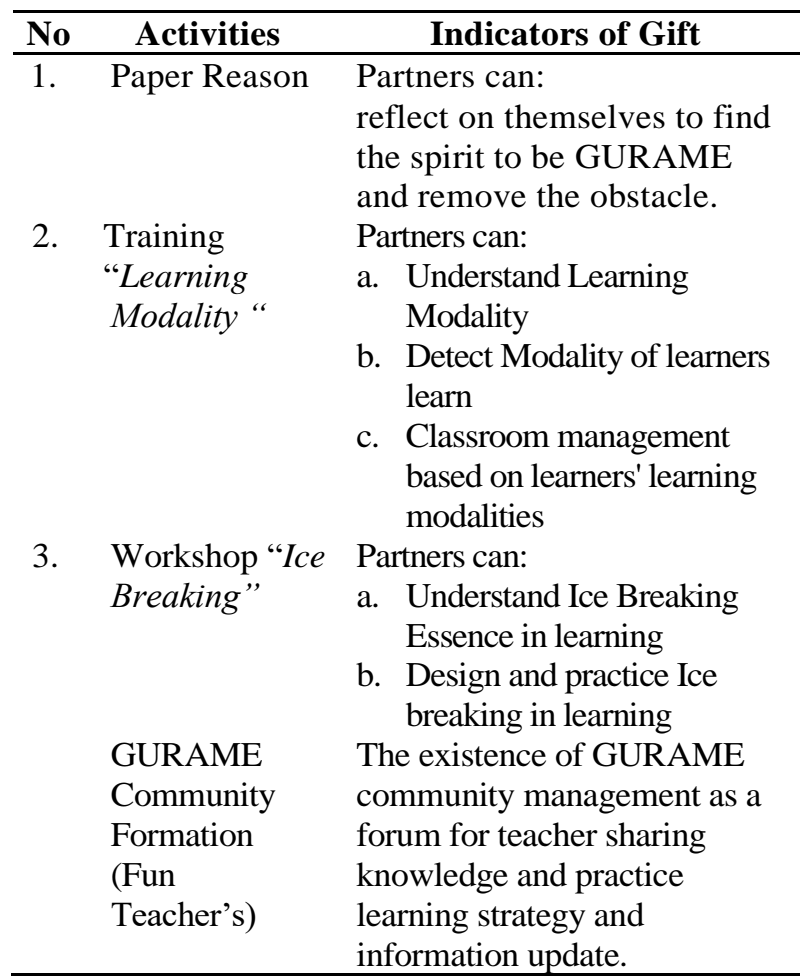

Analysis of this workshop activity is by describing activity based on observation, enthusiasm of all workshop participant with fun activity.

\section{RESULTS AND DISCUSSION}

The enthusiasm of the teachers in joining the activity was high because the contents of the workshop is the answer of their various problems in the class.

The results obtained will be discussed in the following explanation:

\section{Day 1}

The activity started at $14.00 \mathrm{WIB}$, held in Darul Hasan School Hall. Opened by the school side, with 
various welcoming words from Foundation, School, and Principal of each unit of kindergarten, elementary, junior high school. After that, the activity was continued by the Community Service Team of University of Muhammadiyah Tapanuli Selatan with guided moderator Mr. Khalik S. PdI, one of elementary school teachers.

In accordance with the attached curriculum in GURAME, the first speaker guided the participants to reflect the participants' goals as teachers in the paper reason material. Participants reflect themselves for 15 minutes with instrumental music and then write a paper result of his reflection on the goal of becoming a teacher which is now his profession.

As for some questions that must be answered in the paper reason session is:

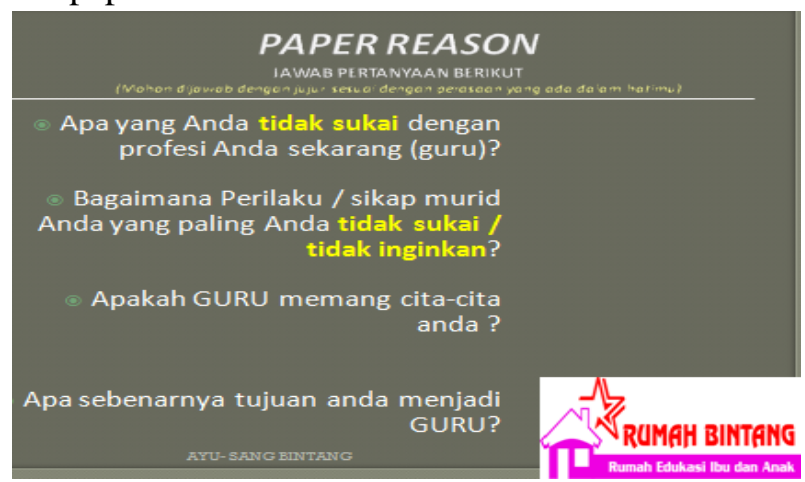

Figure 1. Paper Reason

Then proceed with the Main Material, Learning Modality Detection. In this Material, there is a lot of sharing and discussion from the participants. Some interesting responses are:

1. Why is it so hard to start learning? It takes about 10-15 minutes to be able to initiate the class to start learning?

2. How to teach a disobedient child (fighter and lighter) in class?

3. It is difficult for us to prohibit children from interacting with gadgets, so a lot of children have started to know courtship and being naughty in class. How to restore their interest in class learning?

Interesting questions above were answered by themselves after they get the material learning modality. In closing, participants were asked to reflect and imagine the condition of the class as well as all the students as their class residents. Then they began to detect simply based on the understanding and the characteristics of learning modalities presented by the presenters.

The first day closes with a few words, "ooooo, it's ... the reason that .... (mention the name of the student) so "as well as many other ooo.

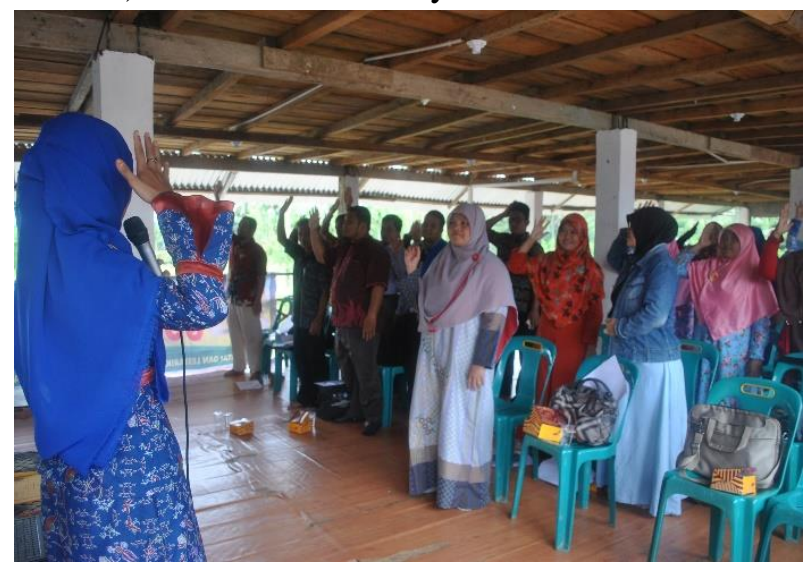

Figure 2. Training activity

\section{Day 2}

The activity began at 09.00 with advanced material how to improve students' learning outcomes with each learning modality. What strategies and methods teachers should do in the classroom. In the final session of learning modality materials, participants were given a simple test of learning modalities to be able to detect their writing modalities in order to be able to use these simple tests on their students.

Then, followed by ice breaking curriculum and closed with the establishment of GURAME Community (Guru Asyik Menyenangkan/Fun Teachers). In each session participants got an exciting ice breaking that makes the atmosphere enjoyable.

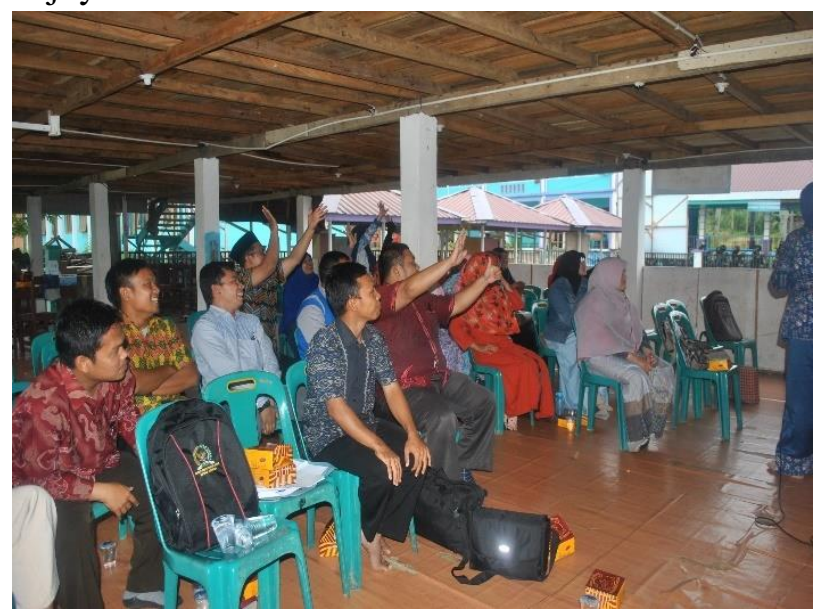

Figure 3. Ice breaking activity

\section{Conclusion}

Based on the results of the GURAME workshop that was already done, the conclusions are: 
1. Obtaining positive feedback from participants i.e. the school, kindergarten teachers, elementary school teachers, and junior high school teachers of Darul Hasan Padang Sidimpuan during the workshop.

2. Increasing knowledge, understanding learning information and class management.

3. The teachers of Darul Hasan Islamic School have been able to understand learning modality and ice breaking and can detect and implement it in the classroom.

4. The high level of enthusiasm and motivation can be seen from the teachers in participating in the workshop, which can be noticed in their activeness to respond as well as the practice of workshop materials.

\section{SUGGESTION}

The need for continuous workshops to enable teachers to upgrade their learning sciences to become fun teachers and to continue GURAME's campaign to teachers of other schools, until they become Trainers.

\section{References}

Gunawan W.Adi ( 2012). Born to be Genius. PT

Gramedia Pustaka Utama.Jakarta

BPS. (2013). Data Statistik Kependudukan. Badan Pusat Statistik Padangsidempuan

Deporter, Bobbi. (2014). Quantum Teaching. PT Mizan Pustaka. Bandung

Sormin Sabrina, Ayunda (2016). Pengantar Pendidikan. SW Publishing. Yogyakarta 